\title{
Behavioural responses of Iberian midwife toad tadpoles (Alytes cisternasii) to chemical stimulus of native (Natrix maura and Squalius pyrenaicus) and exotic (Procambarus clarkii) predators
}

\author{
Vera Gonçalves ${ }^{1, *}$, Sandra Amaral ${ }^{2}$, Rui Rebelo ${ }^{2}$ \\ ${ }^{1}$ Department of Evolutionary Biology "Leo Pardi”, University of Florence, Florence, Italy. \\ ${ }^{2}$ Department of Animal Biology and Centre for Environmental Biology, F.C.U.L., Lisbon, Portugal. \\ * Correspondence: Department of Evolutionary Biology “Leo Pardi”, University of Florence, Via Romana 17, 50125 Florence, Italy. \\ Phone: +055 2288200, Fax: +055 2288309-222565, Email: vera.goncalves@unifi.it
}

Received: 17 March 2011; received in revised form: 1 July 2011; accepted: 25 July 2011.

Predation can be an important force of selection, resulting in the evolution or learning of antipredator defences in amphibian larvae. In the laboratory, we compared the behavioural responses of the tadpoles of Alytes cisternasii subjected to the chemical stimulus of an exotic predator, Procambarus clarkii, with the responses to the chemical stimuli of two of its native predators, the snake Natrix maura and the fish Squalius pyrenaicus, which employ different predation strategies. Tadpoles reacted more intensely to $N$. maura and then to $P$. clarkii, with no significant responses to $S$. pyrenaicus. The alteration in the use of the vertical axis of the aquaria was the antipredator behaviour more frequently used towards both native and exotic predators, and the adopted behaviour was adequate to the activity period and predation strategy of each predator. Alytes cisternasii tadpoles reacted to $P$. clarkii, a predator introduced about 20 years ago in the study area. These reactions may result from a micro-evolutionary process, but may also be a fortuitous response to a non-familiar cue. We can also not discard the possibility of learning by tadpoles since, due to the reproductive characteristics of this species, it was not possible to collect egg masses before their release in the aquatic environment.

Key words. alien predators; Alytes cisternasii; antipredator behaviour; chemoreception; invasions; Procambarus clarkii.

Respuestas conductuales de las larvas de sapo partero ibérico (Alytes cisternasii) a los estímulos químicos de depredadores nativos (Natrix maura y Squalius pyrenaicus) y exóticos (Procambarus clarkii). La depredación es una importante presión selectiva que resulta en la evolución o el aprendizaje de conductas antipredatorias en larvas de anfibios. Comparamos en el laboratorio las respuestas conductuales de larvas de Alytes cisternasii expuestas a los estímulos químicos procedentes de un depredador exótico, Procambarus clarkii, con las respuestas a los estímulos químicos de dos de sus depredadores naturales, la culebra viperina (Natrix maura) y el cacho (Squalius pyrenaicus), los cuales utilizan estrategias de depredación diferentes. Las larvas reaccionaron de manera más intensa a $N$. maura, seguida de $P$. clarkii, sin que existieran respuestas significativas a $S$. pyrenaicus. La alteración en el uso de la columna de agua fue la conducta antipredatoria más utilizada ante los depredadores, ya fueran nativos o exóticos, adecuando las larvas su comportamiento al periodo de actividad y a la estrategia de cada depredador. Las larvas de $A$. cisternasii reaccionaron ante los estímulos procedentes de $P$. clarkii, un depredador introducido tan solo hace 20 años en el área de estudio. Estas reacciones podrían ser resultado de un rápido proceso micro-evolutivo, pero también ser una respuesta fortuita mostrada ante un estímulo novel para las larvas. Tampoco podemos descartar la posibilidad de aprendizaje por parte de las larvas ya que, dadas las características reproductoras de la especie, no fue posible colectar masas de huevos antes de que las larvas eclosionaran y entraran en contacto directo con el medio acuático.

Key words: Alytes cisternasii; conducta antipredatoria; depredadores alóctonos; invasiones; Procambarus clarkii; quimiorrecepción. 
Native and alien predators can be an important force of selection in natural systems, resulting in the evolution or learning of antipredator defences by prey populations. Several studies have demonstrated that larval amphibians are able to innately recognize and respond to coexisting native predators (KATS et al., 1988; SiH \& KATS, 1994; KIESECKER \& BlaUsTEIN, 1997). In larval amphibians, the development of these defences may include changes in life history, morphology or behaviour (SKELLY \& WERNER, 1990; LARDNER, 2000). Antipredator behaviour may include the reduction of activity levels, alterations in the use of different microhabitats or an increased use of refuges (KATS et al., 1988; SKELLY \& WERNER, 1990; KIESECKER et al., 1996; Kiesecker \& Blaustein, 1997; Relyea, 2004; Richter-Boix et al., 2007). Since predators differ in their predation strategies, prey frequently exhibit specific antipredator behaviour (RELYEA, 2001, 2004). Thus, when facing an introduced predator for the first time, naïve native prey may exhibit no antipredator behaviour (KIESECKER \& BLAUSTEIN, 1997; NystrÖM et al., 2001; POLO-CAVIA et al., 2010), or may show behavioural modifications of the antipredator tactics that have evolved as a response to native predators, and that may be inefficient against introduced predators (GAMRADT \& KATS, 1996).

In Portugal, a series of studies have shown that an invading predator, the American red crayfish, Procambarus clarkii (Girard, 1852), predates egg masses and larvae of Southwest Iberian amphibians (CRUZ \& REBELO, 2005) and that this exotic species may exclude several species of these amphibians from their reproduction habitats (CRUZ et al., 2006). It is also known that Iberian midwife toad tadpoles,
Alytes cisternasii Boscá, 1879, show some behavioural modifications when faced with $P$. clarkii, namely by modifying their use of stream bed refuges and by fleeing to the margins during the night (GONÇALVES et al., 2007). Alytes cisternasii is an Iberian endemism commonly found in semi-arid regions. After fertilization, the male carries the string of eggs on its hind legs in the terrestrial environment for about three weeks, after which it deposits the eggs in the water, mainly in small temporary streams (MÁRQUEZ, 1992). In the SW of Portugal these tadpoles take from 3 to 5 months to metamorphose and are subject to predation by a diverse array of aquatic predators (R. Rebelo, personal observation). The types of predator-related stimuli to which these tadpoles are sensitive are not yet clearly identified. However the closely related species Alytes muletensis is known to react to chemical cues of the viperine snake Natrix maura (SCHLEY \& GRIFFITHS, 1998).

In aquatic ecosystems, chemical cues from predators are particularly important for prey in assessing predation risk (KATS \& DILL, 1998). The chemicals to which prey respond may originate from predator-specific odours and/or from cues that are released by disturbed, injured or consumed conspecifics (HETTYEY et al., 2010).

The objective of the present work is to compare the antipredator behaviour of these tadpoles in the presence of chemical cues from $P$. clarkii, and from two of its native predators, the Iberian chub Squalius pyrenaicus (Günther, 1868) and the viperine snake Natrix maura (Linnaeus, 1758). The native predators employ different predation strategies: while the fish is a generalist omnivore that actively searches for prey in the bottom of streams as well as in the water column (BLANCO-GARRIDO et al., 2003), the 
viperine snake is a "sit-and-wait" predator that mostly preys at the bottom or margins of ponds and streams (GONZALO et al., 2008). The predation strategy of $P$. clarkii is intermediate - it actively searches for prey, but effectively only at the bottom of the water bodies (CRUZ \& REBELO, 2005). We expected that tadpoles of A. cisternasii would show appropriate antipredator responses to the chemical cues of their two natural predators, being their similarity with those elicited by the cues of the recently arrived P. clarkii incompletely known.

\section{MATERIALS AND METHODS}

We used data from Amaral (2004), obtained in February 2004 (experiment 1), and performed a similar experiment in AprilMay 2005 (experiment 2). Part of our 2005 results were the subject of a previous paper (GONÇALVES et al., 2007), concerning differences between seasons. The present experiments differed in the native predator used to test tadpoles - experiment 1 tested the effects of $S$. pyrenaicus, while experiment 2 tested the effects of $N$. maura.

All the animals involved in the experiments were captured in the small streams of the Field Station of the CBA - the Herdade da Ribeira Abaixo (Serra de Grândola, Baixo Alentejo, SW Portugal; 3806'28.57”N; 8034'14.56"W). Tadpoles and fishes were captured with dip-nets; crayfishes were captured with baited funnel traps and snakes were captured by hand.

The Portuguese territory south of the Tagus River is a region where no native crayfish ever existed (AlmaÇA, 1991). Tadpoles for both experiments belonged to a population that is in contact with $P$. clarkii since the middle of the 1990s. For each tadpole tested we measured head length (HL, mm) and identified the developmental stage (GOSNER, 1960) (Table 1). These were compared among treatments with a Kruskal-Wallis test. Before the experiments, tadpoles were kept separately in the biotherium of the field station in PVC aquaria filled with spring water for one week, under a 12:12 light-dark photoperiod, and fed ad libitum with cooked lettuce and commercial fish food. The water temperature was kept at $10-14^{\circ} \mathrm{C}$ (experiment 1 ) or $16-18^{\circ} \mathrm{C}$ (experiment 2 ).

Experiments took place in opaque PVC aquaria $(40 \times 60 \times 37.5 \mathrm{~cm})$, with the floor covered with rocks placed in order to mimic a stream bed. Each aquarium was filled with 35 litres of spring water, and we suspended an opaque cage slightly sunk at the surface in the centre of each aquarium. This cage was made with a plastic bottle of 1.5 litres. Its ends were cut and then covered with green net of fine mesh $(2 \mathrm{~mm})$ and the lateral walls were pierced, allowing for the circulation of water. Number of replicates was as follows: experiment 1, empty cage (control treatment), 9 replicates; cage with an individual of $P$. clarkii ('alien predator' treatment), 10 replicates; cage with an individual of S. pyrenaicus ('native predator' treatment) 10 replicates; experiment 2, empty cage (control), 15 replicates; cage with an individual of $P$. clarkii ('alien predator' treatment) 15 replicates; cage with an individual of $N$. maura ('native predator' treatment) 15 replicates. For the trials, the empty cages and the cages with each of the three different predatory species were randomly distributed by the experimental aquaria, and five tadpoles were released in each aquarium right after cage placement. The order of the replicates was random. 
Both experiments ran in two series, first diurnal and then nocturnal. During the night, the tadpoles were observed with a low intensity lantern, having been verified in preliminary tests that this did not affect tadpole behaviour (AMARAL, 2004). Each tadpole, fish and crayfish was used only once; however, the individuals of the diurnal series were used in the corresponding nocturnal series. Due to the difficulty to maintain $N$. maura in captivity, the same two individuals were used in the several replicates. Neither tadpoles nor predators were fed during the experiments; each replicate lasted a maximum of 12 hours.

The choice of the behaviours to record was based on those described for other species (KATS et al., 1988; KIESECKER et al., 1996; KieSECKER \& BlaUstein, 1997; NystrÖM et al., 2001; ALTWEgG, 2002). After being released in the experimental aquarium, tadpoles were given a 30 minute period for acclimatization. Then, we recorded at minutes 30,45 and 60 the following parameters, all consisting in tad- pole counts: 'use of refuges' (under the crevices formed by the stones of the aquarium floor, tadpole totally visible vs. not visible or partially visible), 'activity' (active vs. inactive, activity being defined as any manifestation of movement when the observer saw the tadpole for the first time), 'margin use' (touching the wall of the aquarium or the wall of the cage vs. not touching marginal surfaces) and three variables representing the vertical microhabitat use, 'use of the substratum', 'use of the water column' and 'use of the surface'.

For each replicate, we calculated the average number of tadpoles observed engaged in each behaviour, using the records obtained at 30, 45 and 60 minutes. After checking for normality (using Kolmogorov-Smirnov and Lilliefors tests), the absolute frequencies of each behaviour were compared with one-way analyses of the variance (ANOVAs), followed by Fisher's least significant difference (LSD) post-hoc tests. Instead of using the time of the day as an additional factor in the analysis, the results of diurnal

Table 1: Head length (HL) and developmental stage, according to GOSNER (1960), of tadpoles from experiments 1 and 2 . HL values correspond to mean \pm standard deviation. For the developmental stage the modal class is presented.

\begin{tabular}{cccc}
\hline \hline Variable & Treatment / predator & $\begin{array}{c}\text { Experiment } 1 \text { (Winter) } \\
\text { Amaral (2004) }\end{array}$ & $\begin{array}{c}\text { Experiment 2 (Spring) } \\
\text { Present study }\end{array}$ \\
\hline HL & Control & $17.71 \pm 1.81$ & $15.92 \pm 1.89$ \\
& P. clarkii & $(\mathrm{N}=45)$ & $(\mathrm{N}=75)$ \\
& S. pyrenaicus & $17.26 \pm 1.77$ & $15.78 \pm 1.85$ \\
& & $(\mathrm{~N}=50)$ & $(\mathrm{N}=75)$ \\
& N. maura & $17.90 \pm 1.51$ & - \\
& & $(\mathrm{N}=50)$ & $15.26 \pm 2.13$ \\
Developmental & Control & - & $(\mathrm{N}=75)$ \\
stage & P. clarkii & 25 & 41 \\
& S. pyrenaicus & 25 & - \\
N. maura & 27 & 37 \\
\hline
\end{tabular}


and nocturnal trials were analysed separately because, as stated above, we used the same individuals for both trials. Therefore, the results of both trials were not independent from each other. All analyses were performed with the program Statistica version $5.5\left(\right.$ StatSoft $\left.^{\odot}\right)$.

\section{RESULTS}

\section{Experiment 1}

There were no differences among treatments in tadpole length $\left(\mathrm{H}_{2,145}=2.88, P>0.05\right)$ but there was a difference in developmental stage $\left(\mathrm{H}_{2,145}=\right.$ 11.09, $P<0.01)$; tadpoles from the $S$. pyrenaicus treatment were in a more advanced stage (Table 1 ), presenting slightly longer hind limbs than those shown by tadpoles from the other treatments.

During the day there were no significant differences between the three treatments (control vs. 'alien predator' vs. 'native predator') in any of the behaviours recorded. During the night there were significant differences for the behaviour 'use of refuge' $\left(\mathrm{F}_{2,26}=5.18, P<0.05\right)$. Tadpoles subjected to $P$. clarkii cues decreased the use of refuge compared with tadpoles subjected to the control treatment (LSD test, $P<0.01)$ (Fig.1).

Figure 1: Use of refuges by tadpoles during the diurnal and nocturnal periods in experiment 1 , when they were subjected to chemical cues from an alien predator ( $P$. clarkii) and a native predator (S. pyrenaicus). Values in the ordinate axis refer to the average ( \pm standard error) number of tadpoles manifesting the specified behaviour. Lower case letters $(\mathrm{a}, \mathrm{b})$ refer to groups significantly different $(P<0.05)$ as defined by post-hoc tests.

\section{Experiment 2}

There were not differences among treatments either in tadpole length $\left(\mathrm{H}_{2,225}=0.64, P>0.05\right)$ or in developmental stage $\left(\mathrm{H}_{2,225}=3.80, P>0.05\right)$.

During the day, there were significant differences between treatments in the behaviours 'activity', 'use of the water column' and 'margin use' (Table 2, Fig. 2). All the differences were found between tadpoles subjected to $N$. maura cues and those subjected to the other treatments. Tadpoles subjected to $N$. maura cues were less active, decreased the use of the water column and increased the use of margins (LSD test, $P<0.05$ for all mentioned variables and pair wise comparisons involving $N$. maura).

During the night, there were significant differences for the 'use of the substratum' and for the 'use of the surface' (Table 2, Fig. 3). Tadpoles subjected to $N$. maura cues decreased the use of the substratum and increased their permanence at the surface of the experimental aquarium (LSD test, $P<0.05$ for all mentioned variables and pair wise comparisons involving $N$. maura).

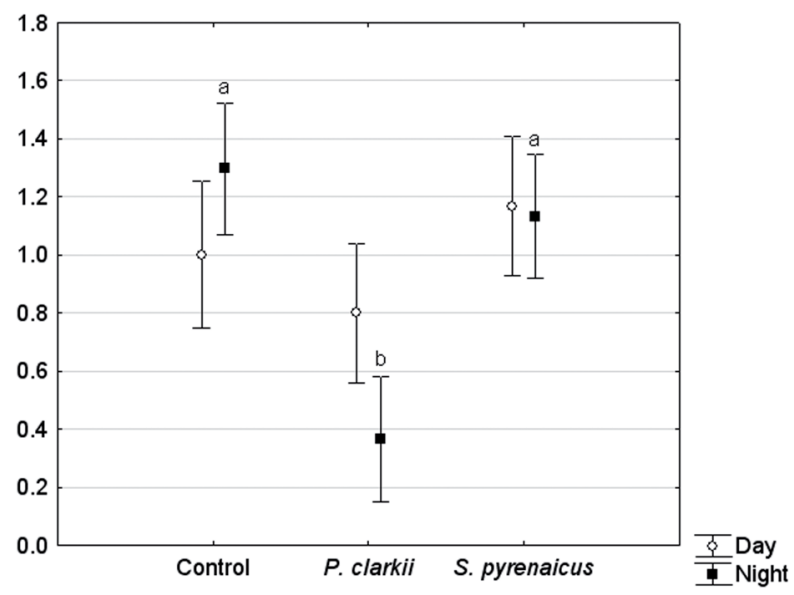


Figure 2: Recorded behaviours of tadpole (a) activity, (b) use of the water column and (c) margin use during the diurnal period in experiment 2, when they were subjected to chemical cues from an alien predator (P. clarkii) and a native predator (N. maura). Values in the ordinate axis refer to the average ( \pm standard error) number of tadpoles manifesting the specified behaviour. Lower case letters $(\mathrm{a}, \mathrm{b})$ refer to groups significantly different $(P<0.05)$ as defined by post-hoc tests.

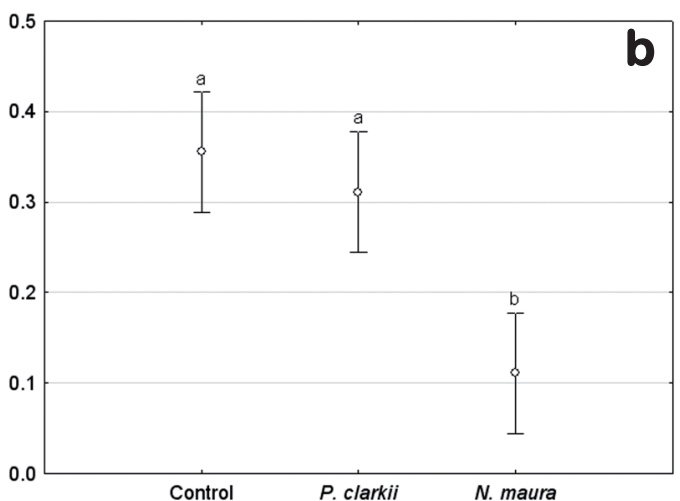

\section{DISCUSSION}

The alteration in the use of the vertical axis of the aquaria by tadpoles seems to be the most common antipredator behaviour shown as a response to the chemical cues from native and alien predators in our experiments, except for $S$. pyrenaicus, towards which we did not find significant responses. In the experiment 2, as expected, tadpoles presented strong antipredator responses to $N$. maura during both nocturnal and diurnal periods. During the day tadpoles decreased their activity and fled from the water column towards the margins, whereas at night tadpoles remained more frequently at the surface. In the laboratory, $N$. maura presents both nocturnal
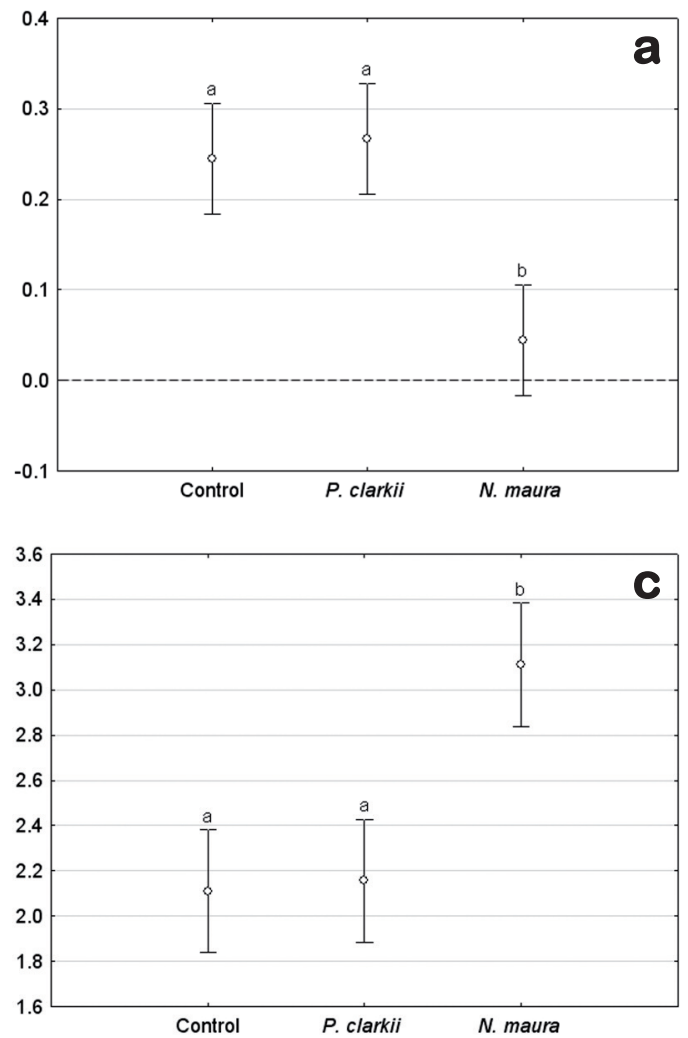

and diurnal activity, using mainly the areas of the aquaria close to the substratum during the day and those close to the margins at night (S. Scali, unpublished data). Therefore, tadpoles diminished the probability of being found in the same microhabitat as their natural predator. The diurnal reduction of activity might also be an adaptive behaviour towards a predator that visually locates its prey (Hailey \& Davies, 1986).

The behavioural responses to $P$. clarkii were best observed in the experiment 1 , with the decrease of the use of refuge during the night. However, this pattern was not found in the experiment 2 , which may be related to the more advanced developmental stages of the tadpoles that were used in this experi- 
Table 2: Results of one-way ANOVAs to compare among treatments tadpole behaviours recorded during the day and during the night in experiment 2. Values in bold indicate significant differences among treatments.

\begin{tabular}{|c|c|c|c|c|c|c|c|c|c|}
\hline \multirow[t]{2}{*}{ Behaviour } & \multirow[t]{2}{*}{ Source of variation } & \multicolumn{4}{|c|}{ Diurnal trials } & \multicolumn{4}{|c|}{ Noctural trials } \\
\hline & & $\begin{array}{l}\text { Sum of } \\
\text { squares }\end{array}$ & d.f. & $\mathrm{F}$ & $P$ & $\begin{array}{l}\text { Sum of } \\
\text { squares }\end{array}$ & d.f. & $\mathrm{F}$ & $P$ \\
\hline \multirow[t]{2}{*}{ Refuge use } & Treatment & 34.53 & 2 & 1.76 & 0.18 & 6.53 & 2 & 0.52 & 0.60 \\
\hline & Error & 412.67 & 42 & & & 264.27 & 42 & & \\
\hline \multirow[t]{2}{*}{ Activity } & Treatment & 4.04 & 2 & 4.03 & $<0.05$ & 0.31 & 2 & 0.44 & 0.65 \\
\hline & Error & 21.07 & 42 & & & 14.93 & 42 & & \\
\hline \multirow[t]{2}{*}{ Water column } & Treatment & 4.58 & 2 & 3.81 & $<0.05$ & 1 & 2 & 0.69 & 0.51 \\
\hline & Error & 25.2 & 42 & & & 3 & 42 & & \\
\hline \multirow[t]{2}{*}{ Substratum } & Treatment & 76.84 & 2 & 2.27 & 0.11 & 88.31 & 2 & 4.89 & $<0.05$ \\
\hline & Error & 710.26 & 42 & & & 378.93 & 42 & & \\
\hline \multirow[t]{2}{*}{ Surface } & Treatment & 86.58 & 2 & 2.21 & 0.12 & 98.8 & 2 & 4.62 & $<0.05$ \\
\hline & Error & 824 & 42 & & & 449.2 & 42 & & \\
\hline \multirow[t]{2}{*}{ Margins } & Treatment & 12 & 2 & 4.31 & $<0.05$ & 21.38 & 2 & 1.23 & 0.30 \\
\hline & Error & 10 & 42 & & & 363.6 & 42 & & \\
\hline
\end{tabular}

ment. As the tadpoles of $A$. cisternasii approach metamorphosis, they tend to spend more time near the surface and margins of the aquaria (GONÇALVES et al., 2007), therefore reducing their presence at the substratum, where refuges were located.

According to our results, $A$. cisternasii tadpoles showed unique behavioural alterations in the presence of $P$. clarkii, different from those shown in the presence of two of their natural predators (based in our results, it is questionable whether $S$. pyrenaicus really constitutes a danger to these tadpoles). This could be an adequate behaviour to compensate for the predation strategy of $P$. clarkii, which is a nocturnal tactile predator, active at the substratum level (HARPER et al., 2002). However, we have no way to positively ascribe this response as an antipredator behaviour adopted towards this alien species or simply as a reaction to a new, unknown cue. To clarify the meaning of this finding, future expe- riments will have to assess the effects of chemical cues of non-predatory novel stimuli that may modify tadpole behaviour by, for instance, providing cues of food availability.

Still, in the case these responses are new and specific to $P$. clarkii, they could be the result of selection. There are several reported cases of prey rapid evolution in response to selection from predator invaders (e.g. SCHLAEPFER et al., 2005; STRAUSS et al., 2006) but, to our knowledge, the shortest time period reported for this to happen in amphibian species is 50-60 years (Kiesecker \& Blaustein, 1997). Another species of the same genus, $A$. muletensis, was shown to be responsive to the chemical cues of $N$. maura, an introduced predator in Majorca island (MOORE et al., 2004), but the introduction of this snake in the island is supposed to have taken place more than 2000 years ago. Our period of coexistence of less than 30 years is quite short in evolutio- 
Figure 3: Recorded behaviours of tadpole (a) use of the substratum and (b) use of the surface during the nocturnal period in experiment 2 , when they were subjected to chemical cues from an alien predator (P. clarkii) and a native predator ( $N$. maura). Values in the ordinate axis refer to the average ( \pm standard error) number of tadpoles manifesting the specified behaviour. Lower case letters $(\mathrm{a}, \mathrm{b})$ refer to groups significantly different $(P<0.05)$ as defined by post-hoc tests

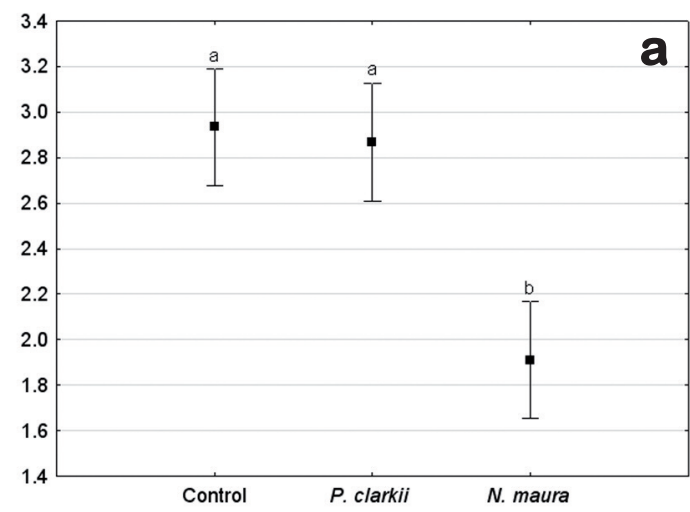

nary time (about $10-15$ generations, given the average lifespan of $A$. cisternasii (GARCÍA-PARÍs et al., 2004)). So, we may be witnessing the result from a learning process, which we cannot exclude, since it is not feasible to collect tadpoles of $A$. cisternasii before hatching and the individuals used in this experiment were thus all collected as tadpoles, with an unknown history of previous contact with $P$. clarkii. Using a completely different approach, a similar resistance of $A$. cisternasii to the effects of $P$. clarkii was also suggested by CRUZ et al. (2006).

Finally, it would be of interest to study the behavioural responses of tadpoles of $A$. cisternasii that have never been in contact with $P$. clarkii when faced with this species.

\section{Acknowledgement}

This work was partially funded by project POCI/BIA-BDE/56100/2004 of Fundação para a Ciência e a Tecnologia (Portugal).

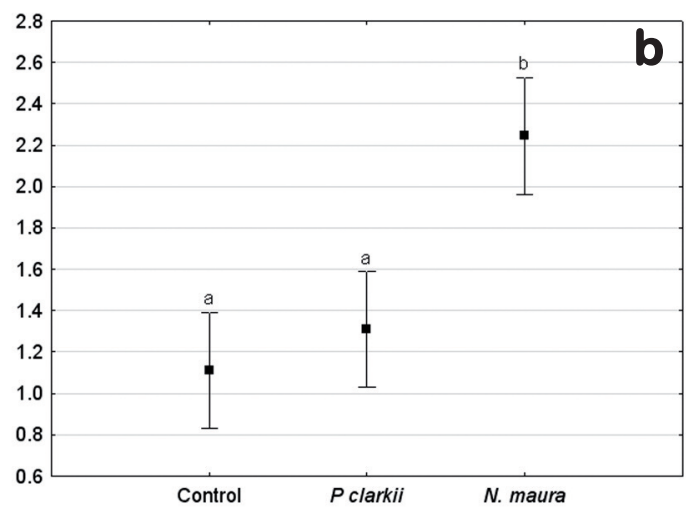

\section{REFERENCES}

AlmaÇA, C. (1991). L'ecrevisse a pieds blancs, Astacus pallipes Lereboullet 1858, au Portugal. L'Astaciculteur de France 28: 11-16.

Altwegg, R. (2002). Predator-induced lifehistory plasticity under time constraints in pool frogs. Ecology 83: 2542-2551.

AMARAL, S. (2004). Respostas comportamentais de girinos de Alytes cisternasii a estimulos quimicos de dois predadores. Internship, Faculdade de Ciências da Universidade de Lisboa, Lisbon, Portugal.

Blanco-Garrido, F.; SÁnChez-Polaina, F.J. \& PRENDA, J. (2003). Summer diet of the Iberian chub (Squalius pyrenaicus) in a Mediterranean stream in Sierra Morena (Yeguas stream, Córdoba, Spain). Limnetica 22: 99-106.

Cruz, M.J. \& Rebelo, R. (2005). Vulnerability of Southwest Iberian amphibians to an introduced crayfish, Procambarus clarkii. Amphibia-Reptilia 26: 293-303. 
Cruz, M.J.; Rebelo, R. \& Crespo, E.G. (2006). Effects of an introduced crayfish, Procambarus clarkii, on the distribution of south-western Iberian amphibians in their breeding habitats. Ecography 29: 329-338.

GamradT, S.C. \& KaTs, L.B. (1996). Effects of introduced crayfish and mosquitofish on California newts. Conservation Biology 10: 1155-1162.

García-París, M.; Montori, A. \& Herrero, P. (2004). Amphibia. Lissamphibia. Series: Fauna Ibérica, vol. 24 (M.A. Ramos, ed.). Museo Nacional de Ciencias Naturales, Madrid, Spain.

Gonçalves, V.; Amaral, S. \& Rebelo, R. (2007). Iberian midwife toad (Alytes cisternasii) tadpoles show behavioural modifications when faced with a recently introduced predator, Procambarus clarkii. Munibe Suplemento-Gehigarria 25: 180-188.

Gonzalo, A.; López, P. \& Martín, J. (2008). Avoidance responses to scents of snakes that pose different risks of predation by adult natterjack toads, Bufo calamita. Canadian Journal of Zoology 86: 928-932. GosNER, K.L. (1960). A simplified table for staging anuran embryos and larvae with notes on identification. Herpetologica 16: 183-190.

Hailey, A. \& Davies, P.M.C. (1986). Diet and foraging behaviour of Natrix maura. Herpetological Journal 1: 53-61.

Harper, D.M.; SMart, A.C.; Coley, S.; SCHMITZ, S.; GOUdER DE BEAUREgARd, A.C.; North, R.; AdAms, C.; OBADE, P. \& Kamau, M. (2002). Distribution and abundance of the Louisiana red swamp crayfish Procambarus clarkii Girard at Lake Naivasha, Kenya between 1987 and 1999. Hydrobiologia 488: 143-151.
HeTtYey, A.; ZsARNÓCZAI, S.; VinCZE, K.; HOI, H. \& LAURILA, A. (2010). Interactions between the information content of different chemical cues affect induced defences in tadpoles. Oikos 119: 1814-1822.

KaTS, L.B. \& Dill, L.M. (1998). The scent of death: Chemosensory assessment of predation risk by prey animals. Ecoscience 5: 361-394.

Kats, L.B.; Petranka, J.W. \& SiH, A. (1988). Antipredator defenses and the persistence of amphibian larvae with fishes. Ecology 69: 1865-1870.

Kiesecker, J.M. \& Blaustein, A.R. (1997). Population differences in responses of redlegged frogs (Rana aurora) to introduced bullfrogs. Ecology 78: 1752-1760.

KieseCKer, J.M.; Chivers, D.P. \& Blaustein, A.R. (1996). The use of chemical cues in predator recognition by western toad tadpoles. Animal Behaviour 52: 1237-1245.

LARDNER, B. (2000). Morphological and life history responses to predators in larvae of seven anurans. Oikos 88: 169-180.

MÁrqueZ, R. (1992). Terrestrial paternal care and short breeding seasons: reproductive phenology of the midwife toads Alytes obstetricans and $A$. cisternasii. Ecography 15: 279-288.

MoOre, R.D.; GrIFFITHS, R.A.; O’BRIEN, C.M.; Murphy, A. \& JaY, D. (2004). Induced defences in an endangered amphibian in response to an introduced snake predator. Oecologia 141: 139-147.

NyströM, P.; SvensSON, O.; LARDNER, B.; BrönMARK, C. \& GranÉlI, W. (2001). The influence of multiple introduced predators on a littoral pond community. Ecology 82: 1023-1039.

Polo-Cavia, N.; Gonzalo, A.; López, P. \& Martín, J. (2010). Predator recognition 
of native but not invasive turtle predators by naïve anuran tadpoles. Animal Behaviour 80: 461-466.

RELYEA, R.A. (2001). The relationship between predation risk and antipredator responses in larval anurans. Ecology 82: 541-554.

RelyeA, R.A. (2004). Fine-tuned phenotypes: tadpole plasticity under 16 combinations of predators and competitors. Ecology 85: 172-179.

Richter-Boix, A.; Llorente, G.A. \& MONTORI, A. (2007). A comparative study of predator-induced phenotype in tadpoles across a pond permanency gradient. Hydrobiologia 583: 43-56.

SCHLAEPFER, M.A.; SHERMAN, P.W.; Blossey, B. $\&$ RUNGE, M.C. (2005). Introduced species as evolutionary traps. Ecology Letters 8: 241-246.
SCHLEY, L. \& GRIFFITHS, R.A. (1998). Midwife toads (Alytes muletensis) avoid chemical cues from snakes (Natrix maura). Journal of Herpetology 32: 572-574.

Sin, A. \& KaTs, L.B. (1994). Age, experience, and the response of streamside salamander hatchlings to chemical cues from predatory sunfish. Ethology 96: 253-259.

Skelly, D.K. \& Werner, E.E. (1990). Behavioral and life-historical responses of larval American toads to an odonate predator. Ecology 71: 2313-2322.

Strauss, S.Y.; Lau, J.A. \& Carroll, S.P. (2006). Evolutionary responses of natives to introduced species: what do introductions tell us about natural communities? Ecology Letters 9: 357-374. 